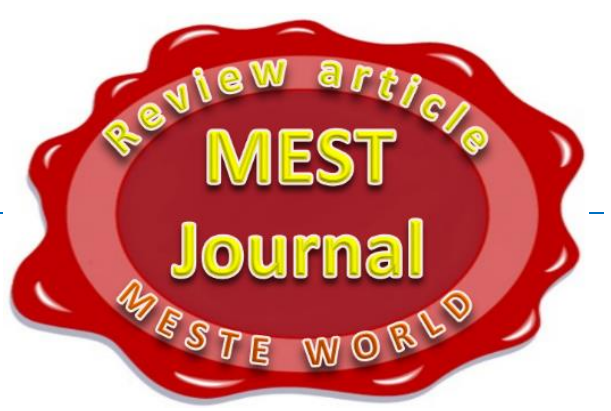

\title{
FEATURES OF IMPROVING THE BUDGETARY SYSTEM OF THE RUSSIAN FEDERATION
}

\author{
Anastasia Kurkina Stanislavovna ${ }^{1}$ \\ International Economic Relations Faculty, Financial University under the \\ Government of the Russian Federation, Moscow, Russia
}

CMESTE

JEL Category: E63, F65

\begin{abstract}
This paper is dedicated to the main directions and areas of the budgetary system of the Russian Federation, functioning of budgets at all levels of the budgetary system, its development, and regulation to adapt the Russian economy to market conditions. This research consists of features that will be further analyzed and discussed. These features are related to improving the functioning budgetary system and the financial system as a whole. This work considers features of the modern budget system of the Russian Federation, analysis of the functioning and execution of the budget system of the Russian Federation on the example of the federal budget, the main problems of the Russian budgetary system, and analysis of possible ways for improving the country's budgetary system. The key aspect of this article is the influence of the current political situation and economic factors on modifying the entire structure of the Russian budget system, as well as its budget policy, to further stabilize the economic development of the state. An important place is given to the formed proposals for improving the functioning budget policy and identified promising areas, which implementation can yield high results in the sphere of the budget system of the Russian Federation.
\end{abstract}

Keywords: budget, finances, modernization, macroeconomic indicators, GDP.

\section{INTRODUCTION}

At present, the financial sector is of great concern to both developed and developing countries. This occurs because the improvement of certain systems, which govern the national economies of

The address of the author:

Anastasia Kurkina Stanislavovna

㶻 nastyaripp@gmail.com some countries, makes it possible to stabilize the budgetary system, which in the future has a key impact as an external system on domestic politics. The Russian Federation is no exception. The main instrument of the financial system and finance as a whole is the budget of the Russian Federation which forms the budgetary system of the country.

To understand how different levels of the Russian Federation's budgets operate, it is necessary to

\footnotetext{
1 Scientific adviser: Dinara Orlova Rustemovna

Department of Economic Theory, Financial University under the Government of the Russian Federation, Moscow, Russia
} 
start with the theoretical component of this financial instrument. Firstly, it is necessary to define the term "budget": it is a form of education as well as expenditure of money, the purpose of which is to ensure some tasks and functions of the state and local self-government. This definition is established by the main legislative act in force in the budgetary sphere and by the Budget Code of the Russian Federation. Budget implementation can be characterized as the accumulation of funds in the hands of the state for exercising governmental authority. The Russian Federation currently has a three-tier budget system: the federal budget, budgets of the constituent entities of the Russian Federation, and local budgets. (Afanasiev \& Shash, 2014) All levels of the budget system are independent. As a result, budgets at all levels operate separately, despite the unity of Russia's current budgetary system. The final part of the budget system of the Russian Federation is a consolidated budget, which is a defined set of budgets of any level, and, more precisely, the combined functioning of the federal, regional, and local budgets of the Russian Federation. (Law, 2020)

\section{ANALYSIS}

Certain macroeconomic indicators affect the functioning of all budget system levels, as well as its formulation and implementation of the state's budgetary policy. These indicators, in their turn, have a direct impact on forming and implementing budget lines in the Russian Federation. Macroeconomic indicators include GDP, real disposable income, and expenditure. (GlobalSecurity.org, 2019) Since the Russian Federation is, to some extent, dependent on the commodity sector, macroeconomic indicators such as exports of goods, namely petroleum products, play an integral part in the functioning of the fiscal system. All the above indicators lead to the following conclusion: for the performance of exports, the performance of dollar/ruble is an important indicator. Such indicators have already been able to take a new turn in the development. The results have been positive in the overall modernization of individual sectors of the national economy.

Table 1. Dynamics of the main parameters of the budget of the Russian Federation since 2017

\begin{tabular}{|c|c|c|c|c|c|c|c|c|}
\hline \multirow{2}{*}{ Indicators } & \multicolumn{2}{|c|}{2017} & \multicolumn{2}{c|}{$\mathbf{2 0 1 8}$ (forecast) } & \multicolumn{2}{c|}{$\mathbf{2 0 1 9}$ (forecast) } & \multicolumn{2}{c|}{$\mathbf{2 0 2 0}$ (forecast) } \\
\cline { 2 - 10 } & $\begin{array}{c}\text { Rubles } \\
\text { (Billions) }\end{array}$ & $\begin{array}{l}\text { Share of } \\
\text { GDP,\% }\end{array}$ & $\begin{array}{c}\text { Rubles } \\
\text { (Billions) }\end{array}$ & $\begin{array}{c}\text { Share of } \\
\text { GDP,\% }\end{array}$ & $\begin{array}{c}\text { Rubles } \\
\text { (Billions) }\end{array}$ & $\begin{array}{l}\text { Share of } \\
\text { GDP,\% }\end{array}$ & $\begin{array}{c}\text { Rubles } \\
\text { (Billions) }\end{array}$ & $\begin{array}{c}\text { Share of } \\
\text { GDP,\% }\end{array}$ \\
\hline Revenues & 14720 & 16.0 & 15258 & 15.7 & 15555 & 15.1 & 16258 & 14.8 \\
\hline Expenses & 17007 & 18.4 & 16529 & 17 & 16374 & 15.9 & 17155 & 15.6 \\
\hline Deficit & 2287 & 2.5 & 1271 & 1.3 & 819 & 0.8 & 870 & 0.8 \\
\hline GDP & 92224 & - & 97462 & - & 103228 & - & 110237 & - \\
\hline
\end{tabular}

Macroeconomic indicators that were considered earlier form the budget policy of the state, therefore, they have a direct impact on forming budget items. The main parameters of the Federal budget of the Russian Federation in the period of 2017-2020 include revenues, expenditures, deficits, and GDP. (Table 1)

The dynamics of the main parameters of the budget of the Russian Federation have certain characteristic features: a gradual decrease in the share of income concerning GDP and a reduction in the share of total expenditures in GDP. (Imazhap \& Ivanova, 2018) On analyzing the presented table, the budget deficit will gradually decrease if the income increases. The revenue part of the budget implies many significant changes that create new tax conditions for the oil and gas sector and other sectors of the national economy. From 2019, a special adjustment coefficient was introduced for export duty rates on fuel and energy products. (Kryukova \& Tugusheva, 2019) Also, the introduction of a negative excise tax on crude oil that is sent for processing to control the increase in domestic prices for petroleum products was implemented in 2019 concerning part of oil and gas revenues. 
Part of non-oil and gas revenues implies an increase in the projected GDP to 98.234 billion rubles. The expected change of volume of imports many goods that are considered to be on the working process, its increase not a few dozen billion rubles. A separate place is given to changing the assessment of income tax receipts for dividends. Revenues from oil and gas revenues, the main source of which is VAT, are expected to slightly exceed $3 \%$ of GDP in the period of 2019-2020 over the volume of revenues from this tax in 2016-2017.

Execution of the Federal budget of the Russian Federation presented some contradictory results. For 2019, nominal revenues increased by 732.8 billion rubles, which eventually amounted to 20187.2 billion rubles. The level of execution of Federal budget revenues concerning the volume of such revenues adopted in 2019 was about $102 \%$. For the entire period of 2019 , the share of tax revenues in the total Federal budget amounted to $75.1 \%$, which increased by $2.3 \%$ compared to 2018.

The volume of expenditures of the Federal budget of the Russian Federation was approved by Federal law "No459" for 2019, which was approved in the amount of 18037.2 billion rubles. The implementation of the changes made to the Federal Law on the Federal budget led to the achievement of such tasks as increasing the budget allocations of the consolidated budget list for Federal budget expenditures. The total amount of the increase was 452.2 billion rubles in 2019 . (Cubrovich \& Egorova, 2015)

The changes introduced to the budget are related to clarifying and adjusting the course of the forecast of socio-economic development of Russia to influence revenues from a large number of revenue sources. Despite this, the system of organizing the budget process that has been formed to date is not functioning in a balanced way. It is a kind of "mixed" model that includes not only elements of budgeting for implemented costs, but also the management of the current system, which, in turn, is aimed at achieving the set results. Budgeting plays an important role in this aspect. A distinctive feature of the introduction and use of budgeting elements is their diversity, the variability of their combination, the organization of functioning of well-coordinated "approaches" - all this requires the use of these innovative tools, which make the implementation of budget management possible. (Federal law 380-FZ, 2019)

Over the past 10 years of the existence of budgeting elements, the Russian Federation has lagged behind the desired development dynamics. (Poryadina, Alina, \& Kabasheva, 2018) However, the key year was 2018 , as, despite the slowdown in the global economy, the growth of the Russian economy accelerated up to $2.3 \%$. Therefore, this result allows to identify trends that are considered positive and strengthen their positions in the structure of economic growth:

1. Dynamic production growth in numerous branches, the key feature of which is the development and further strengthening of competitiveness of Russian national economy through the export growth in the oil and gas sector as well as achieving strong results of operating profitability;

2. Strengthening and developing a favorable investment climate. This is due to the growth of investment in fixed assets.

3. The structure of financing sources is becoming more stable by reducing the role of external debt resources. Also, the role of the domestic financial market is gaining more relevance and significance.

These trends are the changes that allowed both financial and economic policies to acquire a new round of development. It was thanks to their implementation that the process of creating some macroeconomic policy institutions was organized; the current system of inter-budgetary relations was reformed. A significant breakthrough was the strengthening of the formation and control of the operational profitability of budget execution.

Operational efficiency in the use of budget funds is one of the national goals for the development of the budget system and policy of the Russian Federation. Operational efficiency refers to a specific set of measures that are implemented to improve the efficiency of budget expenditures. As mentioned earlier, Federal programs are being implemented, the monitoring system of which is provided with the transparency of actions taken, and the ability to control the use of budget funds. (Pechenskaya-Polishchuk, 2020) 
The financial system, which includes the budget system and implementation of the budget policy, needs to be modernized to meet the current conditions in modern Russia. This concerns the modernization of the state's economy. To carry out a comprehensive reform, it is necessary to create certain conditions that will help achieve such results as improving the efficiency of economic development, bringing competitiveness to a new level, which, in its turn, will affect the attractiveness of the investment climate. (Omelekhina, 2017)

Any changes should initially be considered from the point of view of their possible impact on the pace of developing the national economy, and in general, on the population welfare, business activity, etc.

In the history of the Russian economy, there was a period associated with the "Dutch disease", when strengthening or weakening of the ruble during periods of growth or decline in oil prices led to a change in the state of competitiveness of Russian industrial companies not only in the domestic market but also in the external market. "The Dutch disease" had a strong impact on the services sector. This led to the fact that any previously stable functioning sector was directly dependent on oil prices. This period turned out to be cyclical. In 2020, a similar model of high interdependence of oil quotes and exchange rate ratios of national and foreign currencies is being formed.

A sharp weakening of the ruble was caused by the "Coronavirus" phenomenon. Construction of "budget rules" meant creating conditions for the development of competitive industries, not the oil and gas sector, to reduce the dependence of their financial results on oil prices. In today's reality, it is impossible to reduce the dependence on public finances due to the dynamics of established oil prices.

For the stable functioning of a large number of sectors of the national economy at the legislative level, it is important to fix the rules for the entry into force of such elements of taxation that worsen the current situation of taxpayers. The modified tax conditions should provoke a demand for confidence in the restructured budget and tax policy, which, in turn, can further contribute to the attractiveness of the investment climate. (MFRF, 2019)

Regarding the subjects of the Russian Federation, they should be considered from the outside. These measures include:

- Providing opportunities for subjects of the right to establish an investment tax deduction for innovative activities, stimulating the creation of research works.

- Exercise of the right to tax deduction on excise taxes for certain enterprises and organizations whose activity is the production of fuel and energy products using ethane raw materials. This should be introduced to ensure the development of projects in the petrochemical sector and the introduction of conditions that encourage increased involvement in the deep processing of such raw materials.

Every system constantly requires special attention and modernization to achieve better results. An important point in the analysis of the financial sector and the budgetary system is the peculiarity of improving the budgets of various levels of the budgetary system of the Russian Federation. Thanks to these features, it can be understood how the current budgetary system has been functioning during the past five years. (Poryadina, Alina, \& Kabasheva, 2018) The first peculiarity to be highlighted is the existence of such principles as "budgetary rules" which allow comparing the influence of price fluctuation on the world market with the internal conditions of the prevailing macroeconomic situation. Such changes have reduced the oil and gas deficit to minimal levels. The volume of oil and gas revenues in 2018 amounted to 4,261.4 billion rubles, which were eventually redirected to the National Welfare Fund in 2019. The next significant feature is the establishment of a list of public tax expenditures legal entities and annual evaluation of collected data in the BC of the Russian Federation for forming and organizing the accounting system, as well as evaluating the efficiency of tax expenditures at all levels of budgets. The increase in the budget allocations of the consolidated budget to federal budget expenditures is an important innovation that has led to an increase in the total volume by 452.2 billion rubles. (GlobalSecurity.org, 2019) 


\section{CONCLUSIONS}

By the end of 2020, positive results can be achieved only if the right direction for improving the functioning of the Russian budgetary system is chosen. Firstly, macroeconomic stability should be reached, which could lead to a substantial reduction in the deficit as well as the prevention of inflation-related indicators. Secondly, it is necessary to consider the area of income, some modifications will ensure the efficient functioning of the tax system. An important aspect of improving the existing budgetary system is interbudgetary transfers from the federal budget to the budgets of the constituent entities of the Russian
Federation, as all resources are concentrated only at the disposal of the federal budget. The savings system also needs to be reorganized, namely, to be modernized. While the fiscal policy should contribute to a stable fiscal environment, the current fiscal policy over the past two years has not been entirely consistent with this trend. An increase in the VAT rate from 18 to 20 percent has temporarily enhanced inflation, slowed down the economic growth, and weakened investment performance. To improve the functioning of the budget system, it is necessary to create more conditions for the investment climate for implementing infrastructure projects.

\section{WORKS CITED}

Afanasiev, M. P., \& Shash, N. N. (2014). The introduction of program budgeting in Russia: 20 years of experience with Russian budgetary reforms. Retrieved 12 02, 2020, from Public Administration Issues: https://cyberleninka.ru/article/n/the-introduction-of-program-budgeting-in-russia-20years-of-experience-with-russian-budgetary-reforms/viewer

Cubrovich, J. A., \& Egorova, M. S. (2015). Gosudarstvennyy byudzhet i yego rol' v ekonomike. Young scientist, 10(90), 834-837. Retrieved from https://moluch.ru/archive/90/18781/

Federal law 380-FZ. (2019, 12 02). Federal law No. 380-FZ of 02.12.2019 (as amended on 18.03.2020) "On the Federal budget for 2020 and for the planning period of 2021 and 2022". . Retrieved from Konsul'tantPlyus: http://www.consultant.ru/document/cons_doc_LAW_339305/

GlobalSecurity.org. (2019, 05 16). Russian State Budget. Retrieved from GlobalSecurity.org: https://www.globalsecurity.org/military/world/russia/budget.htm

Imazhap, B. Y., \& Ivanova, Y. A. (2018). Dokhody i raskhody federal'nogo byudzheta Rossiyskoy Federatsii / B. YU. Imazhap, YU. A. Ivanova. Molodoy uchenyy, 15(201), 19-22. Retrieved from https://moluch.ru/archive/201/49276/

Kryukova, O. A., \& Tugusheva, A. F. (2019). On certain issues of budget and legal regulation /. Young scientist, 2(240), 134-135. Retrieved from https://moluch.ru/archive/240/55467/

Law. (2020, 04 22). Byudzhetnyy kodeks Rossiyskoy Federatsii" ot 31.07.1998 N 145-FZ. Retrieved from Konsul'tantPlyus: http://www.consultant.ru/document/cons_doc_LAW_19702/

MFRF. (2019). Byudzhetnyy prognoz Rossiyskoy Federatsii na period do 2036 goda. Moskva: Ministerstvo finansov RF. Retrieved from https://www.minfin.ru/common/upload/library/2019/04/main/Budzhetnyy_prognoz_2036_1.pdf

Omelekhina, N. V. (2017). Budget system of the Russian Federation in the system of financial security institutions of the state. Journal of Russian law(1), 81-95.

Pechenskaya-Polishchuk, M. A. (2020). Tools and principles of redistribution of budget resources in the region. Economic and social changes: facts, trends, forecast, 13(2), 71-88. doi:10.15838/esc.2020.2.68.5

Poryadina, I., Alina, G., \& Kabasheva, N. (2018). The role of the State Budget in the country's economy: dynamics, assessment, forecast. Scientific Journal "Discuss", 2(16), 136-146. 
Received for publication:

Revision received:

04.09 .2020

Accepted for publication:
16.09 .2020

30.12 .2020

\section{How to cite this article?}

Style - APA Sixth Edition:

Kurkina, A. S. (2021, January 15). Features of improving the budgetary system of the Russian Federation. (Z. Cekerevac, Ed.) MEST Journal, 9(1), 84-89. doi:10.12709/mest.09.09.01.11

Style - Chicago Sixteenth Edition:

Kurkina, Anastasia Stanislavovna. 2021. "Features of improving the budgetary system of the Russian Federation." Edited by Zoran Cekerevac. MEST Journal (MESTE) 9 (1): 84-89. doi:10.12709/mest.09.09.01.11.

Style - GOST Name Sort:

Kurkina Anastasia Stanislavovna Features of improving the budgetary system of the Russian Federation [Journal] // MEST Journal / ed. Cekerevac Zoran. - Belgrade - Toronto : MESTE, January 15, 2021. - 1 : Vol. 9. - pp. 84-89.

Style - Harvard Anglia:

Kurkina, A. S., 2021. Features of improving the budgetary system of the Russian Federation. MEST Journal, 15 January, 9(1), pp. 84-89.

Style - ISO 690 Numerical Reference:

Features of improving the budgetary system of the Russian Federation. Kurkina, Anastasia Stanislavovna. [ed.] Zoran Cekerevac. 1, Belgrade - Toronto : MESTE, January 15, 2021, MEST Journal, Vol. 9, pp. 84-89. 